\title{
Homeostatic plasticity in neural development
}

\author{
Nai-Wen Tien ${ }^{1,2^{*}}$ and Daniel Kerschensteiner ${ }^{1,3,4,5^{*}}$ (D)
}

\begin{abstract}
Throughout life, neural circuits change their connectivity, especially during development, when neurons frequently extend and retract dendrites and axons, and form and eliminate synapses. In spite of their changing connectivity, neural circuits maintain relatively constant activity levels. Neural circuits achieve functional stability by homeostatic plasticity, which equipoises intrinsic excitability and synaptic strength, balances network excitation and inhibition, and coordinates changes in circuit connectivity. Here, we review how diverse mechanisms of homeostatic plasticity stabilize activity in developing neural circuits.
\end{abstract}

Keywords: Homeostatic plasticity, Neural development, Intrinsic excitability, Synaptic strength, Excitation/inhibition ratio, Patterned spontaneous activity

\section{Background}

Nervous systems face a constant challenge: how to maintain flexibility and stability at the same time. Neural circuits must stay flexible to allow for changes in connectivity and synaptic strength during development and learning. As changes in connectivity push neural circuits away from equilibrium, they need to maintain activity within a working range and avoid extremes of quiescence and saturation. Functional stability is maintained by homeostatic plasticity, which is defined broadly as a set of neuronal changes that restore activity to a setpoint following perturbation [1-3]. Recent studies have identified diverse homeostatic plasticity mechanisms triggered by a variety of perturbations. These mechanisms regulate dendritic and axonal connectivity of a neuron, as well as its intrinsic excitability (Fig. 1). In addition to maintaining the activity of individual neurons, homeostatic plasticity can act at a network level to coordinate changes in connectivity and excitability across multiple neurons to stabilize circuit function [4] (Fig. 2). Several recent reviews have covered the function of homeostatic plasticity in the mature nervous system [5-8]. Here, we focus on homeostatic plasticity in developing circuits.

\footnotetext{
*Correspondence: tien@wustl.edu; kerschensteinerd@wustl.edu ${ }^{1}$ Department of Ophthalmology and Visual Sciences, Washington University School of Medicine, Saint Louis, USA

Full list of author information is available at the end of the article
}

\section{Homeostatic regulation of intrinsic excitability}

Neuronal intrinsic excitability is determined by the density, distribution, and function of ion channels, and controls how synaptic inputs are converted into action potential outputs [9]. Several studies have found a reciprocal relationship between intrinsic excitability and synaptic inputs across development, which stabilizes activity [10-12]. As synaptic inputs increase in developing Xenopus retinotectal circuits, $\mathrm{Na}^{+}$currents decrease, reducing intrinsic excitability [12]. Conversely, silencing synaptic inputs to developing Xenopus tectal neurons and Drosophila motorneurons increases $\mathrm{Na}^{+}$ currents and intrinsic excitability [10, 12, 13]. Several mechanisms mediate homeostatic changes in $\mathrm{Na}^{+}$currents. Translational repression and post-translational phosphorylation reduce the density and open probability, respectively, of voltage-gated $\mathrm{Na}^{+}$channels in Drosophila motorneurons and rat cortical neurons in response to elevated synaptic activity [11, 14-17].

Multiple ion channels in the same neuron can balance each other to stabilize activity $[2,18,19]$. For example, the A-type $\mathrm{K}^{+}$channels shal and shaker are reciprocally regulated in motorneurons of Drosophila larvae: shaker is up-regulated in shal mutants, and shal is up-regulated in shaker mutants [20]. However, compensatory expression is not always a two-way street; in Drosophila mutants of the delayed rectifier $\mathrm{K}^{+}$channel shab, increased expression of the $\mathrm{Ca}^{2+}$-dependent $\mathrm{K}^{+}$channel slo prevents motorneuron hyperactivity, but, loss of slo does not increase expression 


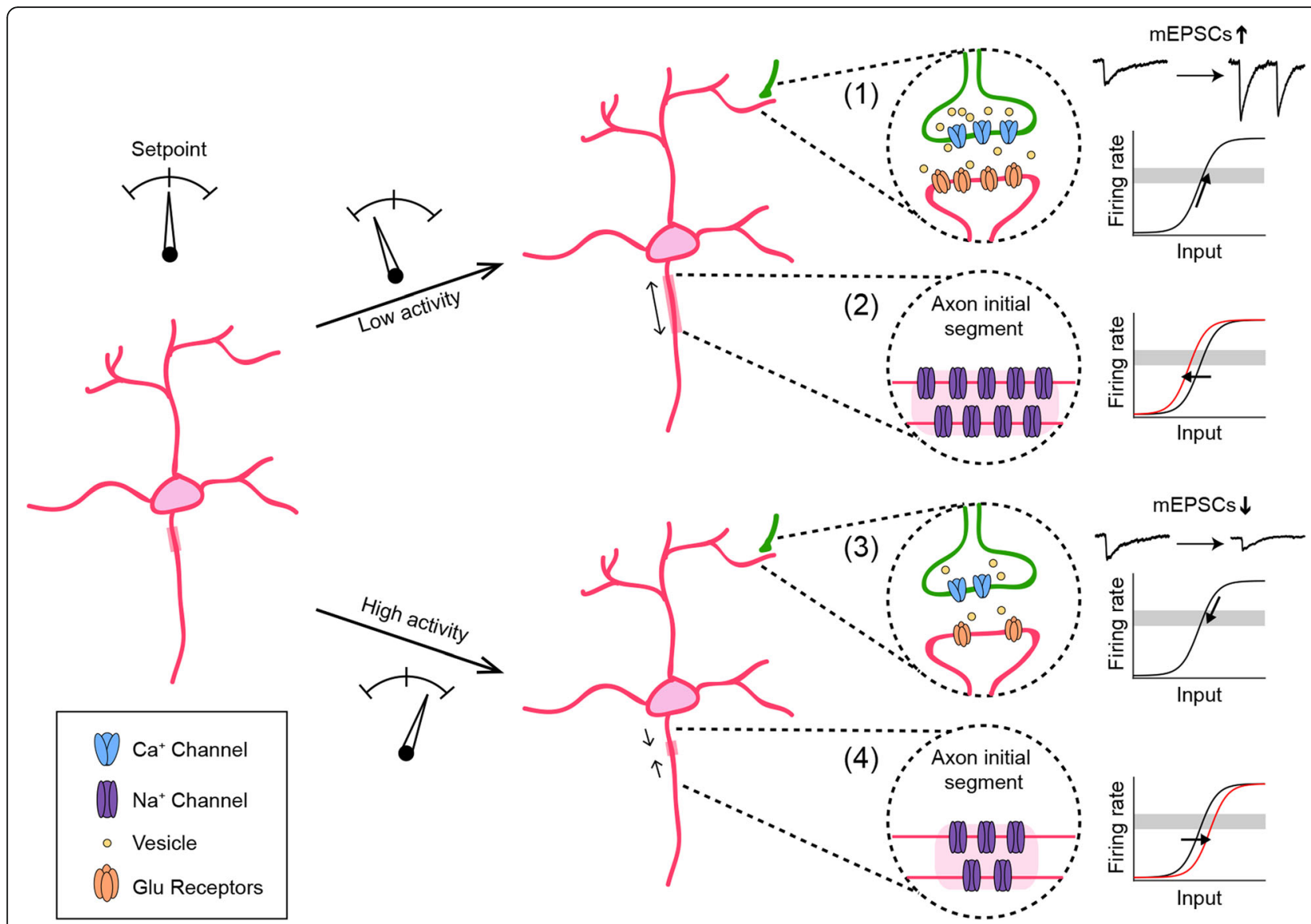

Fig. 1 Diverse homeostatic plasticity mechanisms stabilize the activity of developing neurons. When the activity of individual neurons decreases below (1 and 2) or increases above (3 and 4) a setpoint, homeostatic regulation of synaptic strength ( 1 and 3 ) and/or intrinsic excitability (2 and 4) acts to restore normal activity. By increasing (1) or decreasing (3) synaptic input (e.g., changes in mEPSC amplitude or frequency), a neuron's output firing rate can be shifted up or down to the target activity (grey area). By increasing (2) or decreasing (4) intrinsic excitability (e.g., changes in the length and location of AIS), a neuron's input/output relationship can be modified

of shab [21]. Neurons can synergistically regulate ion channels with opposite effects on excitability to restore activity. Silencing of pyramidal neurons cultured from visual cortex of rat pups with TTX increases $\mathrm{Na}^{+}$currents and decreases $\mathrm{K}^{+}$currents [22]. Finally, neurons of the same type with similar excitability can vary significantly in their membrane conductances, which may reflect the complex homeostatic interactions between ion channels [23-25] (for more discussion, see [26, 27]).

Detailed examination of the distribution of ion channels revealed an important role of the axon-initialsegment (AIS) in intrinsic homeostatic plasticity. Changes in length and location of the AIS, a specialized region with clusters of voltage-gated $\mathrm{Na}^{+}$and $\mathrm{K}^{+}$ channels involved in spike generation, can counter the effects of sensory deprivation or photostimulation [28-31]. In mice, eye opening at postnatal day 13-14 shortens the AIS of pyramidal neurons in visual cortex [32, 33]. Together, adjustments in ion channel density, distribution, and function, resulting from changes in transcription, translation, post-translational modifications, and trafficking, can alter intrinsic excitability and balance changes in synaptic input to maintain activity homeostasis $[9,34-36]$.

Homeostatic regulation of synapse strength and number Homeostatic plasticity can regulate synaptic strength pre- and postsynaptically, and its dominant expression site can shift during development. In the early stages of network formation, miniature excitatory postsynaptic current (mEPSC) amplitudes increase when spike generation is blocked in cortical and hippocampal neuron cultures (i.e., suppression of intrinsic excitability), indicative of postsynaptic changes in AMPA receptor accumulation [37]. At later stages, presynaptic regulation of vesicle release and recycling is added, and mEPSC frequencies increase along with mEPSC amplitudes when spike generation is blocked [37, 38]. This suggests a developmental shift in the capacity for pre- and postsynaptic homeostatic plasticity [37]. Homeostatic control of synaptic strength 


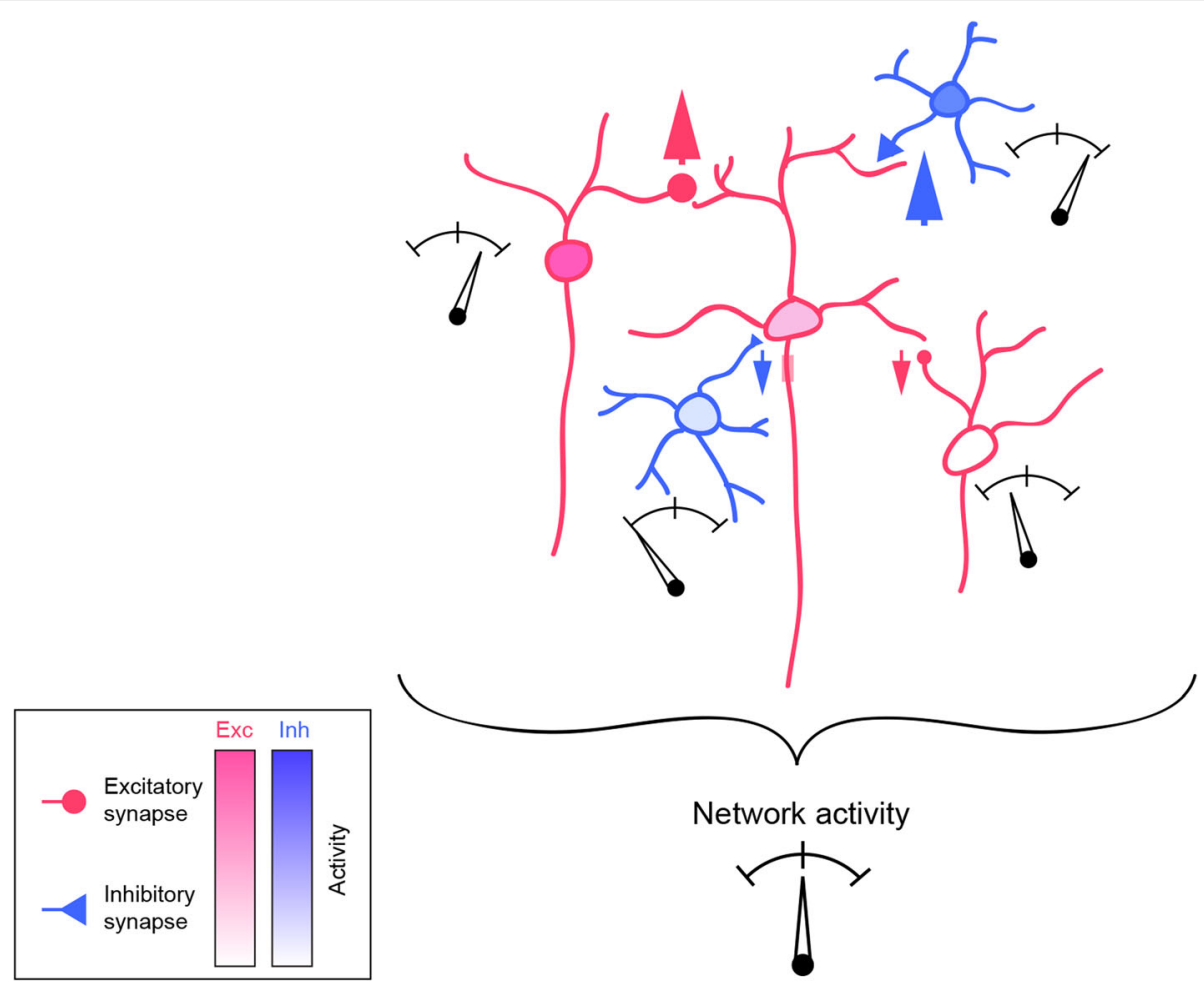

Fig. 2 Network-level homeostatic plasticity stabilizes activity of developing circuits. Network activity homeostasis is achieved by balancing excitation (red) and inhibition (blue). Synaptic strength and connectivity can be regulated in a cell-type-specific manner to maintain network homeostasis. Upward/downward red arrows: increased/decreased excitatory drive; upward/downward blue arrows: increased/decreased inhibitory drive

has also been observed in vivo $[39,40]$. The extent and expression site of this control depends on circuit maturation [41-45]. Homeostatic synaptic plasticity in layers 4 and 6 of primary visual cortex elicited by visual deprivation is restricted to an early critical period (postnatal day 16 to 21 ) $[42,43]$. Later, homeostatic regulation of mEPSC amplitudes shifts to layers $2 / 3$, where it persists into adulthood $[42,44]$. The purpose of this shift in homeostatic plasticity across cortical layers remains unknown [41]. Chronic activity suppression by intracranial infusion of the $\mathrm{Na}^{+}$ channel blocker TTX or NMDA receptor blockers increases spine densities of developing thalamocortical neurons in the dorsolateral geniculate nucleus of cats and ferrets $[46,47]$. Thus, homeostatic plasticity can regulate synapse number as well as strength [48-50].

In addition to homeostatic synaptic changes elicited by experimental perturbations, Desai et al. showed that across development, mEPSC amplitudes in layers $2 / 3$ and 4 of rat primary visual cortex decrease as mEPSC frequencies and synapse numbers increase [42]. Retinogeniculate circuits provide another example of developmental homeostatic co-regulation [51-53]. Initially, many retinal ganglion cells converge onto thalamocortical cells, each forming weak connections. Then, for up to 3 weeks after eye opening, thalamocortical cells prune inputs, retaining synapses from fewer ganglion cells, which strengthen their connections $[53,54]$. Thus, presynaptic neurotransmitter release, postsynaptic receptor abundance, and synapse number are homeostatically coregulated during normal development and after activity perturbations. In several systems, the expression sites and the combination of mechanisms engaged shift across development [2, 3, 55-57].

\section{Homeostatic regulation of network activity}

Homeostatic plasticity can stabilize the activity of individual neurons $[54,58,59]$. Neurons connect to each other in a cell-type-specific manner, forming circuits that perform specific functions. In the following sections, we discuss how homeostatic mechanisms are coordinated across neurons to stabilize circuit function $[4,60]$.

\section{Homeostatic regulation of network excitation and inhibition}

Network activity is determined by the ratio of excitation and inhibition (E/I ratio) $[1,4,61]$. In response to perturbations, developing circuits can differentially adjust inhibitory and excitatory connectivity to alter the E/I ratio and restore activity [62-65]. In developing hippocampal and organotypic cerebellar cultures, TTX or glutamate receptor antagonists decrease inhibitory synapse densities and strengths, whereas blocking GABAergic transmission with bicuculline increases the density of 
inhibitory synapses. Similarly, brain slice recordings in barrel cortex layer 4 showed that sensory deprivation selectively reduces inhibitory input to layer 4 spiny neurons in young but not in adult animals [66, 67]. Activity-dependent changes in inhibitory synaptic transmission appear to be regulated non-cell autonomously, as activity suppression of individual presynaptic or postsynaptic cells failed to elicit compensatory changes observed after global application of TTX in neonatal cultured hippocampal neurons [65]. It has been suggested that inhibitory interneurons may sacrifice their own firing rate homeostasis to stabilize spiking of cortical pyramidal neurons after global activity blockade $[4,68]$. Another example of network homeostasis comes from studies of monocular deprivation during the critical period [4]. Here, homeostatic plasticity adjusts recurrent and feedforward connections between layer 4 circuits and layer $2 / 3$ circuits in primary visual cortex. Visual deprivation via intraocular TTX injection increases the excitatory drive and reduces inhibitory drive from layer 4 to layer $2 / 3$, compensating for the lost excitatory sensory input [4, 69, 70]. Intriguingly, in another deprivation paradigm (i.e., lid suture), increased intrinsic excitability and decreased E/I ratios stabilize activity in layer $2 / 3$, indicating the same circuit can use different combinations of homeostatic mechanisms to compensate for sensory deprivation.

In addition to regulating excitatory and inhibitory synapse strength and number, homeostatic plasticity can switch the transmitter phenotype of neurons from glutamate to GABA or vice versa to adjust the E/I ratio of developing circuits [71-73]. In the embryonic Xenopus spinal cord, the fractions of neurons expressing excitatory transmitters increase and decrease, respectively, when network activity is pharmacologically suppressed and enhanced. These switches in transmitter phenotype occur without changes in the expression of cell identity markers [74]. Similar to homeostatic regulation of inhibitory synapses, the activity-dependent transmitter switch is non-cell autonomous and depends on network activity, evidenced by the reciprocal relationship between the number of silenced cells and the ratio of neurons expressing GABA vs. glutamate [75]. Whether switches in transmitter phenotypes contribute to network homeostasis during normal development remains to be investigated [71].

\section{Homeostatic regulation of cell-type-specific connectivity} Recent advances in single-cell RNA sequencing together with large-scale morphological and functional surveys have revealed a great diversity of excitatory and inhibitory cell types, which serve distinct circuit functions [76-79]. This raises the questions whether, beyond categorical differences between excitatory and inhibitory neurons, homeostatic plasticity may act in a cell-typespecific manner to stabilize circuit function [80]. In the developing dentate gyrus, loss of excitatory drive by tetanus toxin expression results in reduced inhibitory input to granule cells [81]. This reduction is cell-type specific, affecting somatic innervation by parvalbumin-positive basket cells, but not dendritic innervation by calretininand somatostatin-expressing interneurons. Selective reduction of somatic inhibition efficiently restores the firing of granule cells [82, 83]. Similarly, monocular deprivation during a pre-critical period was shown to regulate feedback but not feedforward inhibition to layer 4 pyramidal cells in rat primary visual cortex [84]; and early hearing loss weakens inhibitory synapses from fastspiking interneurons but not from low-threshold spiking interneurons onto pyramidal cells $[85,86]$.

Homeostatic regulation of excitatory connectivity can also be cell type specific [87]. In the developing mouse retina, following removal of their dominant B6 bipolar cell input, $\mathrm{ON \alpha}$ retinal ganglion cells up-regulate connectivity with $\mathrm{XBC}, \mathrm{B} 7$, and rod bipolar cells, but leave input from B8 bipolar cells unchanged. This cell-typespecific rewiring not only maintains the sustained activity of $\mathrm{ON \alpha}$ retinal ganglion cells, but also precisely preserves their light responses. Thus, homeostatic plasticity can regulate inhibitory and excitatory connectivity in a cell-type-specific manner to maintain the activity and sensory function of developing circuits.

Homeostatic regulation of patterned spontaneous activity Throughout the nervous system, developing circuits spontaneously generate activity patterns that help refine their connectivity $[88,89]$. Before eye opening, waves of activity originating in the retina propagate through the visual system and dominate activity up to primary visual cortex [90-92]. Retinal waves mature in three stages (I-III), in which different circuit mechanisms generate distinct activity patterns that serve specific functions in visual system refinement [88]. In mice, stage I waves, which are mediated by gap-junctional coupling of retinal ganglion cells, were first observed at embryonic day 17. Around birth, the wave generation switches to networks of cholinergic amacrine cells (stage II, postnatal day 1-10) followed in the second postnatal week by glutamatergic input from bipolar cells (stage III, postnatal day 10-14). The transitions between stages appear to be homeostatically regulated. When stage II (i.e., cholinergic) waves are disrupted by genetic deletion or pharmacological blockade of $\beta 2$ nicotinic acetylcholine receptors nAChRs, stage I waves persist until premature stage III waves take over [93-96]. Similarly, in VGluT1 knockout mice, in which stage III waves are abolished, stage II waves persist until eye opening [97]. Studies of developing 
spinal networks revealed an important role of excitatory GABAergic currents in homeostatic regulation of patterned spontaneous activity [98]. During development, GABA switches from excitatory to inhibitory as initially high intracellular $\mathrm{Cl}^{-}$concentrations are lowered by the developmentally regulated expression of cationchloride cotransporters $[99,100]$. When spontaneous network activity in chick embryos was reduced by injection of a sodium channel blocker, excitatory GABAergic mEPSC amplitudes were found to increase because of an increased $\mathrm{Cl}^{-}$driving force due to intracellular $\mathrm{Cl}^{-}$ accumulation [101, 102].

Although homeostatic mechanisms can restore spontaneous activity patterns following perturbations, the extent to which these activity patterns support normal circuit refinement varies depending on age and means of perturbation and needs to be further investigated [103-105].

\section{Conclusions}

Developing circuits undergo profound changes in connectivity that threaten to destabilize their activity. Recent research has revealed a diverse set of homeostatic plasticity mechanisms, which safeguard activity of developing circuits. Different combinations of these mechanisms are recruited by different perturbations in different neuronal cell types at different stages of development. What signals control the recruitment of specific combinations of mechanisms is unclear and an interesting topic for future studies $[41,55]$.

Another important and mostly unanswered question is how activity setpoints are determined [2, 106-108]. Recent evidence suggests that this may occur during specific critical periods of development $[109,110]$. Altering network activity in wild-type Drosophila during a critical period induces subsequent seizures, whereas correcting abnormal activity in mutant flies during the same period is sufficient to suppress seizures for life. Importantly, in the seizure-prone flies, homeostatic plasticity mechanisms are intact, but working toward the "wrong" setpoints. Insights into critical period timing and determinants of activity setpoints could have significant implications for the treatment of neurodevelopmental diseases including epilepsy and autisms [111-114].

\section{Abbreviations}

AIS: Axon-initial-segment; E/I: Excitation/Inhibition; mEPSC: miniature excitatory postsynaptic current

\section{Funding}

Work of the authors was supported by funding from the National Institutes of Health (NIH EY023441, EY026978, and EY027411)
Authors' contributions

$\mathrm{N}-\mathrm{WT}$ and DK wrote the manuscript. Both authors read and approved the final manuscript.

Ethics approval and consent to participate

Not applicable.

\section{Competing interests}

The authors declare that they have no competing interests.

\section{Publisher's Note}

Springer Nature remains neutral with regard to jurisdictional claims in published maps and institutional affiliations.

\section{Author details}

'Department of Ophthalmology and Visual Sciences, Washington University School of Medicine, Saint Louis, USA. ${ }^{2}$ Graduate Program in Neuroscience, Washington University School of Medicine, Saint Louis, USA. ${ }^{3}$ Department of Neuroscience, Washington University School of Medicine, Saint Louis, USA. ${ }^{4}$ Department of Biomedical Engineering, Washington University School of Medicine, Saint Louis, USA. ${ }^{5}$ Hope Center for Neurological Disorders, Washington University School of Medicine, Saint Louis, MO 63110, USA

Received: 9 January 2018 Accepted: 24 April 2018

Published online: 01 June 2018

\section{References}

1. Turrigiano GG, Nelson SB. Homeostatic plasticity in the developing nervous system. Nat Rev Neurosci. 2004;5(2):97-107.

2. Davis GW. Homeostatic signaling and the stabilization of neural function. Neuron. 2013;80(3):718-28.

3. Wefelmeyer W, Puhl CJ, Burrone J. Homeostatic plasticity of subcellular neuronal structures: from inputs to outputs. Trends Neurosci. 2016;39(10):656-67.

4. Maffei A, Fontanini A. Network homeostasis: a matter of coordination. Curr Opin Neurobiol. 2009:19(2):168-73.

5. Fox K, Stryker M. Integrating Hebbian and homeostatic plasticity: introduction. Philos Trans R Soc Lond Ser B Biol Sci. 2017;372(1715). https:// doi.org/10.1098/rstb.2016.0413

6. Turrigiano GG. The dialectic of Hebb and homeostasis. Philos Trans R Soc Lond Ser B Biol Sci. 2017;372(1715). https://doi.org/10.1098/rstb.2016.0258.

7. Turrigiano GG. The self-tuning neuron: synaptic scaling of excitatory synapses. Cell. 2008;135(3):422-35.

8. Vitureira N, Goda Y. Cell biology in neuroscience: the interplay between Hebbian and homeostatic synaptic plasticity. J Cell Biol. 2013;203(2):175-86.

9. Beck H, Yaari Y. Plasticity of intrinsic neuronal properties in CNS disorders. Nat Rev Neurosci. 2008:9(5):357-69.

10. Baines RA, Uhler JP, Thompson A, Sweeney ST, Bate M. Altered electrical properties in Drosophila neurons developing without synaptic transmission. J Neurosci. 2001;21(5):1523-31.

11. Baines RA. Postsynaptic protein kinase a reduces neuronal excitability in response to increased synaptic excitation in the Drosophila CNS. J Neurosci. 2003;23(25):8664-72.

12. Pratt KG, Aizenman CD. Homeostatic regulation of intrinsic excitability and synaptic transmission in a developing visual circuit. J Neurosci. 2007;27(31): 8268-77.

13. Hamodi AS, Pratt KG. Region-specific regulation of voltage-gated intrinsic currents in the developing optic tectum of the Xenopus tadpole. J Neurophysiol. 2014;112(7):1644-55.

14. Mee CJ, Pym EC, Moffat KG, Baines RA. Regulation of neuronal excitability through pumilio-dependent control of a sodium channel gene. J Neurosci. 2004:24(40):8695-703.

15. Muraro NI, Weston AJ, Gerber AP, Luschnig S, Moffat KG, Baines RA. Pumilio binds Para mRNA and requires Nanos and brat to regulate sodium current in Drosophila motoneurons.J Neurosci. 2008:28(9):2099-109.

16. Driscoll HE, Muraro NI, He M, Baines RA. Pumilio-2 regulates translation of Nav1.6 to mediate homeostasis of membrane excitability. J Neurosci. 2013; 33(23):9644-54

17. Scheuer T. Regulation of sodium channel activity by phosphorylation. Semin Cell Dev Biol. 2011;22(2):160-5. 
18. Turrigiano G, LeMasson $G$, Marder E. Selective regulation of current densities underlies spontaneous changes in the activity of cultured neurons. J Neurosci. 1995;15(5 Pt 1):3640-52.

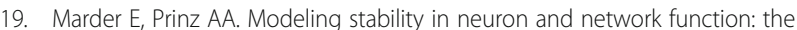
role of activity in homeostasis. Bioessays. 2002;24(12):1145-54.

20. Bergquist S, Dickman DK, Davis GW. A hierarchy of cell intrinsic and targetderived homeostatic signaling. Neuron. 2010;66(2):220-34.

21. Kim EZ, Vienne J, Rosbash M, Griffith LC. Nonreciprocal homeostatic compensation in Drosophila potassium channel mutants. J Neurophysiol. 2017; 117(6):2125-36.

22. Desai NS, Rutherford LC, Turrigiano GG. Plasticity in the intrinsic excitability of cortical pyramidal neurons. Nat Neurosci. 1999;2(6):515-20.

23. Schulz DJ, Goaillard JM, Marder E. Variable channel expression in identified single and electrically coupled neurons in different animals. Nat Neurosci. 2006;9(3):356-62.

24. Golowasch J, Goldman MS, Abbott LF, Marder E. Failure of averaging in the construction of a conductance-based neuron model. J Neurophysiol. 2002; 87(2):1129-31

25. Schulz DJ. Plasticity and stability in neuronal output via changes in intrinsic excitability: it's what's inside that counts. J Exp Biol. 2006;209(Pt 24):4821-7.

26. O'Leary T, Williams AH, Caplan JS, Marder E. Correlations in ion channel expression emerge from homeostatic tuning rules. Proc Natl Acad Sci U S A. 2013;110(28):E2645-54

27. Hudson AE, Prinz AA. Conductance ratios and cellular identity. PLoS Comput Biol. 2010;6(7):e1000838.

28. Grubb MS, Burrone J. Activity-dependent relocation of the axon initial segment fine-tunes neuronal excitability. Nature. 2010;465(7301):1070-4.

29. Kuba $\mathrm{H}$, Oichi $Y$, Ohmori $\mathrm{H}$. Presynaptic activity regulates $\mathrm{Na}(+)$ channel distribution at the axon initial segment. Nature. 2010;465(7301):1075-8.

30. Evans MD, Dumitrescu AS, Kruijssen DLH, Taylor SE, Grubb MS. Rapid modulation of axon initial segment length influences repetitive spike firing. Cell Rep. 2015;13(6):1233-45.

31. Yin J, Yuan Q. Structural homeostasis in the nervous system: a balancing act for wiring plasticity and stability. Front Cell Neurosci. 2014;8:439.

32. Gutzmann A, Ergul N, Grossmann R, Schultz C, Wahle P, Engelhardt M. A period of structural plasticity at the axon initial segment in developing visual cortex. Front Neuroanat. 2014:8:11.

33. Petersen AV, Cotel F, Perrier JF. Plasticity of the axon initial segment: fast and slow processes with multiple functional roles. Neuroscientist. 2016;23(4): 364-73

34. Temporal S, Lett KM, Schulz DJ. Activity-dependent feedback regulates correlated ion channel mRNA levels in single identified motor neurons. Current biology : CB. 2014;24(16):1899-904.

35. Zhang W, Linden DJ. The other side of the engram: experience-driven changes in neuronal intrinsic excitability. Nat Rev Neurosci. 2003;4(11): 885-900.

36. Frick A, Johnston D. Plasticity of dendritic excitability. J Neurobiol. 2005; 64(1):100-15.

37. Wierenga CJ, Walsh MF, Turrigiano GG. Temporal regulation of the expression locus of homeostatic plasticity. J Neurophysiol. 2006:96(4):2127-33.

38. Burrone J, O'Byrne M, Murthy VN. Multiple forms of synaptic plasticity triggered by selective suppression of activity in individual neurons. Nature. 2002;420(6914):414-8.

39. Kaneko M, Stryker MP. Homeostatic plasticity mechanisms in mouse V1. Philos Trans R Soc Lond Ser B Biol Sci. 2017;372(1715). https://doi.org/10. 1098/rstb.2016.0504.

40. Johnson RE, Tien NW, Shen N, Pearson JT, Soto F, Kerschensteiner D. Homeostatic plasticity shapes the visual system's first synapse. Nat Commun. 2017;8(1):1220.

41. Turrigiano G. Homeostatic synaptic plasticity: local and global mechanisms for stabilizing neuronal function. Cold Spring Harb Perspect Biol. 2012;4(1): a005736.

42. Desai NS, Cudmore RH, Nelson SB, Turrigiano GG. Critical periods for experience-dependent synaptic scaling in visual cortex. Nat Neurosci. 2002;5(8):783-9.

43. Petrus E, Anguh TT, Pho H, Lee A, Gammon N, Lee HK. Developmental switch in the polarity of experience-dependent synaptic changes in layer 6 of mouse visual cortex. J Neurophysiol. 2011;106(5):2499-505.

44. Goel A, Lee HK. Persistence of experience-induced homeostatic synaptic plasticity through adulthood in superficial layers of mouse visual cortex. J Neurosci. 2007;27(25):6692-700.
45. Espinosa JS, Stryker MP. Development and plasticity of the primary visual cortex. Neuron. 2012;75(2):230-49.

46. Dalva MB, Ghosh A, Shatz CJ. Independent control of dendritic and axona form in the developing lateral geniculate nucleus. J Neurosci. 1994;14(6): 3588-602.

47. Rocha M, Sur M. Rapid acquisition of dendritic spines by visual thalamic neurons after blockade of N-methyl-D-aspartate receptors. Proc Natl Acad Sci U S A. 1995;92(17):8026-30.

48. Pak DT, Sheng M. Targeted protein degradation and synapse remodeling by an inducible protein kinase. Science. 2003;302(5649):1368-73.

49. Seeburg DP, Sheng M. Activity-induced polo-like kinase 2 is required for homeostatic plasticity of hippocampal neurons during epileptiform activity. J Neurosci. 2008;28(26):6583-91.

50. Lee KJ, Lee Y, Rozeboom A, Lee JY, Udagawa N, Hoe HS, Pak DT. Requirement for Plk2 in orchestrated ras and rap signaling, homeostatic structural plasticity, and memory. Neuron. 2011;69(5):957-73.

51. Chen C, Regehr WG. Developmental remodeling of the retinogeniculate synapse. Neuron. 2000;28(3):955-66.

52. Jaubert-Miazza L, Green E, Lo FS, Bui K, Mills J, Guido W. Structural and functional composition of the developing retinogeniculate pathway in the mouse. Vis Neurosci. 2005;22(5):661-76.

53. Hooks BM, Chen C. Distinct roles for spontaneous and visual activity in remodeling of the retinogeniculate synapse. Neuron. 2006;52(2):281-91.

54. Lin DJ, Kang E, Chen C. Changes in input strength and number are driven by distinct mechanisms at the retinogeniculate synapse. J Neurophysiol. 2014;112(4):942-50.

55. Davis GW, Muller M. Homeostatic control of presynaptic neurotransmitter release. Annu Rev Physiol. 2015;77:251-70.

56. Burrone J, Murthy VN. Synaptic gain control and homeostasis. Curr Opin Neurobiol. 2003;13(5):560-7.

57. Oleskevich S, Walmsley B. Synaptic transmission in the auditory brainstem of normal and congenitally deaf mice. J Physiol. 2002;540(Pt 2):447-55.

58. Echegoyen J, Neu A, Graber KD, Soltesz I. Homeostatic plasticity studied using in vivo hippocampal activity-blockade: synaptic scaling, intrinsic plasticity and age-dependence. PLoS One. 2007;2(8):e700.

59. Lambo ME, Turrigiano GG. Synaptic and intrinsic homeostatic mechanisms cooperate to increase L2/3 pyramidal neuron excitability during a late phase of critical period plasticity. J Neurosci. 2013;33(20):8810-9.

60. Slomowitz E, Styr B, Vertkin I, Milshtein-Parush H, Nelken I, Slutsky M, Slutsky I. Interplay between population firing stability and single neuron dynamics in hippocampal networks. elife. 2015;4:e04378.

61. Pozo K, Goda Y. Unraveling mechanisms of homeostatic synaptic plasticity. Neuron. 2010:66(3):337-51.

62. Chattopadhyaya B, Di Cristo G, Higashiyama H, Knott GW, Kuhlman SJ, Welker E, Huang ZJ. Experience and activity-dependent maturation of perisomatic GABAergic innervation in primary visual cortex during a postnatal critical period. J Neurosci. 2004;24(43):9598-611.

63. Marty S, Wehrle R, Sotelo C. Neuronal activity and brain-derived neurotrophic factor regulate the density of inhibitory synapses in organotypic slice cultures of postnatal hippocampus. J Neurosci. 2000;20(21):8087-95.

64. Seil FJ, Drake-Baumann R. Reduced cortical inhibitory synaptogenesis in organotypic cerebellar cultures developing in the absence of neuronal activity. J Comp Neurol. 1994;342(3):366-77.

65. Hartman KN, Pal SK, Burrone J, Murthy VN. Activity-dependent regulation of inhibitory synaptic transmission in hippocampal neurons. Nat Neurosci. 2006;9(5):642-9.

66. Jiao $Y$, Zhang C, Yanagawa $Y$, Sun QQ. Major effects of sensory experiences on the neocortical inhibitory circuits. J Neurosci. 2006;26(34):8691-701.

67. Flores CE, Mendez P. Shaping inhibition: activity dependent structural plasticity of GABAergic synapses. Front Cell Neurosci. 2014;8:327.

68. Rutherford LC, Nelson SB, Turrigiano GG. BDNF has opposite effects on the quantal amplitude of pyramidal neuron and interneuron excitatory synapses. Neuron. 1998;21(3):521-30.

69. Maffei A, Nataraj K, Nelson SB, Turrigiano GG. Potentiation of cortical inhibition by visual deprivation. Nature. 2006;443(7107):81-4.

70. Maffei A, Turrigiano GG. Multiple modes of network homeostasis in visual cortical layer 2/3. J Neurosci. 2008;28(17):4377-84.

71. Borodinsky LN, Belgacem YH, Swapna I, Sequerra EB. Dynamic regulation of neurotransmitter specification: relevance to nervous system homeostasis. Neuropharmacology. 2014:78:75-80.

72. Spitzer NC. Neurotransmitter switching? No surprise. Neuron. 2015;86(5):1131-44. 
73. Spitzer NC. Neurotransmitter switching in the developing and adult brain. Annu Rev Neurosci. 2017;40:1-19.

74. Borodinsky LN, Root CM, Cronin JA, Sann SB, Gu X, Spitzer NC. Activitydependent homeostatic specification of transmitter expression in embryonic neurons. Nature. 2004;429(6991):523-30.

75. Guemez-Gamboa A, Xu L, Meng D, Spitzer NC. Non-cell-autonomous mechanism of activity-dependent neurotransmitter switching. Neuron. 2014;82(5):1004-16.

76. Tasic B, Menon V, Nguyen TN, Kim TK, Jarsky T, Yao Z, Levi B, Gray LT, Sorensen SA, Dolbeare T, et al. Adult mouse cortical cell taxonomy revealed by single cell transcriptomics. Nat Neurosci. 2016;19(2):335-46.

77. Cembrowski MS, Wang L, Sugino K, Shields BC, Spruston N. Hipposeq: a comprehensive RNA-seq database of gene expression in hippocampal principal neurons. elife. 2016;5:e14997.

78. Toledo-Rodriguez M, Markram H. Single-cell RT-PCR, a technique to decipher the electrical, anatomical, and genetic determinants of neuronal diversity. Methods Mol Biol. 2007;403:123-39.

79. Bloodgood BL, Sharma N, Browne HA, Trepman AZ, Greenberg ME. The activity-dependent transcription factor NPAS4 regulates domain-specific inhibition. Nature. 2013;503(7474):121-5.

80. Bartley AF, Huang ZJ, Huber KM, Gibson JR. Differential activity-dependent, homeostatic plasticity of two neocortical inhibitory circuits. J Neurophysiol. 2008;100(4):1983-94.

81. Pieraut S, Gounko N, Sando R 3rd, Dang W, Rebboah E, Panda S, Madisen L, Zeng $\mathrm{H}$, Maximov A. Experience-dependent remodeling of basket cell networks in the dentate gyrus. Neuron. 2014;84(1):107-22.

82. Miles R, Toth K, Gulyas Al, Hajos N, Freund TF. Differences between somatic and dendritic inhibition in the hippocampus. Neuron. 1996;16(4):815-23.

83. Pouille F, Scanziani M. Enforcement of temporal fidelity in pyramidal cells by somatic feed-forward inhibition. Science. 2001;293(5532):1159-63.

84. Maffei A, Nelson SB, Turrigiano GG. Selective reconfiguration of layer 4 visual cortical circuitry by visual deprivation. Nat Neurosci. 2004;7(12):1353-9.

85. Takesian AE, Kotak VC, Sanes DH. Presynaptic GABA(B) receptors regulate experience-dependent development of inhibitory short-term plasticity. J Neurosci. 2010;30(7):2716-27.

86. Takesian AE, Kotak VC, Sharma N, Sanes DH. Hearing loss differentially affects thalamic drive to two cortical interneuron subtypes. J Neurophysiol. 2013; 110(4):999-1008

87. Tien NW, Soto F, Kerschensteiner D. Homeostatic plasticity shapes cell-typespecific wiring in the retina. Neuron. 2017;94(3):656-65. e654

88. Blankenship AG, Feller MB. Mechanisms underlying spontaneous patterned activity in developing neural circuits. Nat Rev Neurosci. 2010;11(1):18-29.

89. Kerschensteiner D. Spontaneous network activity and synaptic development. J Neurosci. 2014;20(3):272-90.

90. Ackman JB, Burbridge TJ, Crair MC. Retinal waves coordinate patterned activity throughout the developing visual system. Nature. 2012;490(7419):219-25.

91. Assali A, Gaspar P, Rebsam A. Activity dependent mechanisms of visual map formation-from retinal waves to molecular regulators. Semin Cell Dev Biol. 2014;35:136-46.

92. Arroyo DA, Feller MB. Spatiotemporal features of retinal waves instruct the wiring of the visual circuitry. Front Neural Circuits. 2016;10:54.

93. Stacy RC, Demas J, Burgess RW, Sanes JR, Wong RO. Disruption and recovery of patterned retinal activity in the absence of acetylcholine. J Neurosci. 2005; 25(41):9347-57.

94. Sun C, Warland DK, Ballesteros JM, van der List D, Chalupa LM: Retinal waves in mice lacking the beta2 subunit of the nicotinic acetylcholine receptor. Proc Natl Acad Sci U S A 2008, 105(36):13638-13643.

95. Stafford BK, Sher A, Litke AM, Feldheim DA. Spatial-temporal patterns of retinal waves underlying activity-dependent refinement of retinofugal projections. Neuron. 2009;64(2):200-12.

96. Bansal A, Singer JH, Hwang BJ, Xu W, Beaudet A, Feller MB. Mice lacking specific nicotinic acetylcholine receptor subunits exhibit dramatically altered spontaneous activity patterns and reveal a limited role for retinal waves in forming ON and OFF circuits in the inner retina. J Neurosci. 2000;20(20):7672-81.

97. Blankenship AG, Ford KJ, Johnson J, Seal RP, Edwards RH, Copenhagen DR, Feller MB. Synaptic and extrasynaptic factors governing glutamatergic retinal waves. Neuron. 2009;62(2):230-41.

98. Wenner P. Homeostatic synaptic plasticity in developing spinal networks driven by excitatory GABAergic currents. Neuropharmacology. 2014;78:55-62.

99. Ben-Ari Y, Gaiarsa JL, Tyzio R, Khazipov R. GABA: a pioneer transmitter that excites immature neurons and generates primitive oscillations. Physiol Rev. 2007;87(4):1215-84.
100. Blaesse P, Airaksinen MS, Rivera C, Kaila K. Cation-chloride cotransporters and neuronal function. Neuron. 2009;61(6):820-38.

101. Gonzalez-Islas C, Wenner P. Spontaneous network activity in the embryonic spinal cord regulates AMPAergic and GABAergic synaptic strength. Neuron. 2006:49(4):563-75

102. Gonzalez-Islas C, Chub N, Garcia-Bereguiain MA, Wenner P. GABAergic synaptic scaling in embryonic motoneurons is mediated by a shift in the chloride reversal potential. J Neurosci. 2010;30(39):13016-20.

103. Torborg $\mathrm{CL}$, Feller MB. Spontaneous patterned retinal activity and the refinement of retinal projections. Prog Neurobiol. 2005;76(4):213-35.

104. Huberman AD, Wang GY, Liets LC, Collins OA, Chapman B, Chalupa LM. Eyespecific retinogeniculate segregation independent of normal neuronal activity. Science. 2003;300(5621):994-8.

105. Torborg CL, Hansen KA, Feller MB. High frequency, synchronized bursting drives eye-specific segregation of retinogeniculate projections. Nat Neurosci. 2005;8(1):72-8.

106. Giachello CN, Baines RA. Regulation of motoneuron excitability and the setting of homeostatic limits. Curr Opin Neurobiol. 2017;43:1-6.

107. Hobert O. Terminal selectors of neuronal identity. Curr Top Dev Biol. 2016; 116:455-75.

108. Marder E, Goaillard JM. Variability, compensation and homeostasis in neuron and network function. Nat Rev Neurosci. 2006;7(7):563-74.

109. Giachello CN, Baines RA. Inappropriate neural activity during a sensitive period in embryogenesis results in persistent seizure-like behavior. Current biology : CB. 2015;25(22):2964-8.

110. Truszkowski TL, Aizenman CD. Neurobiology: setting the set point for neural homeostasis. Current biology : CB. 2015;25(23):R1132-3.

111. Ramocki MB, Zoghbi HY. Failure of neuronal homeostasis results in common neuropsychiatric phenotypes. Nature. 2008;455(7215):912-8.

112. Meredith RM, Dawitz J, Kramvis I. Sensitive time-windows for susceptibility in neurodevelopmental disorders. Trends Neurosci. 2012;35(6):335-44.

113. Mullins C, Fishell G, Tsien RW. Unifying views of autism Spectrum disorders: a consideration of autoregulatory feedback loops. Neuron. 2016;89(6):1131-56.

114. Vislay RL, Martin BS, Olmos-Serrano JL, Kratovac S, Nelson DL, Corbin JG, Huntsman MM. Homeostatic responses fail to correct defective amygdala inhibitory circuit maturation in fragile X syndrome. J Neurosci. 2013;33(17) 7548-58.

\section{Ready to submit your research? Choose BMC and benefit from:}

- fast, convenient online submission

- thorough peer review by experienced researchers in your field

- rapid publication on acceptance

- support for research data, including large and complex data types

- gold Open Access which fosters wider collaboration and increased citations

- maximum visibility for your research: over $100 \mathrm{M}$ website views per year

At BMC, research is always in progress.

Learn more biomedcentral.com/submissions 